\title{
Review
}

\section{A Review of Papillary Renal Cell Carcinoma and MET Inhibitors}

\author{
Katherine Emilie Rhoades Smith ${ }^{\mathrm{a}}$ and Mehmet Asim Bilen ${ }^{\mathrm{b}, *}$ \\ ${ }^{a}$ Department of Medicine, Emory University School of Medicine, Atlanta, GA, USA \\ ${ }^{\mathrm{b}}$ Department of Hematology and Medical Oncology, Winship Cancer Institute of Emory University, \\ Atlanta, GA, USA
}

\begin{abstract}
Papillary renal cell carcinoma (PRCC) is a subtype of renal cell carcinoma (RCC) accounting for approximately 15-20\% of cases and further divided into Type 1 and Type 2. Type 1 PRCC tends to have more alterations in the MET tyrosine kinase receptor than Type 2 PRCC. Treatment for RCC patients is based on studies with minimal participation from patients with PRCC; consequently, conventional therapies tend to be less effective for RCC patients with a subtype other than ccRCC (non-ccRCC). Since MET is a known alteration in PRCC, it is potential target for directed therapy. There have been many attempts to develop MET inhibitors for use in solid tumors including PRCC. The following review will discuss the current research regarding MET-targeted therapy, MET inhibitors in clinical trials, and future directions for MET inhibitors in PRCC.
\end{abstract}

Keywords: Papillary renal carcinoma, kidney cancer, renal cell cancer, molecularly targeted therapies, immune-checkpoint inhibitor, non-clear cell renal cell carcinoma, MET

\section{INTRODUCTION}

Renal cell carcinoma (RCC) is the sixth most commonly diagnosed cancer in men and the tenth in women with approximately 140,000 deaths yearly, ranking $\mathrm{RCC}$ as the 13th most common cause of cancer death worldwide [1-4]. The lifetime risk for developing RCC in Europe and North America is $1.3 \%-1.8 \%$. In the United States, there are 15.9 cases per 100,000 each year with a $0.6 \%$ increase each year in new cases of kidney and renal pelvis cancer over the last decade [5]. Papillary renal cell carcinoma (PRCC) is the second most common type of RCC, following clear cell carcinoma (ccRCC), comprising $15-20 \%$ of RCC cases. PRCC is further subdivided into type 1 and type 2 based on histology. Although

\footnotetext{
${ }^{*}$ Correspondence to: Dr. Mehmet Asim Bilen, Department of Hematology and Medical Oncology, Winship Cancer Institute of Emory University, Atlanta, GA, USA. Tel.: +1 404778 3693; Fax: +1 404778 8584; E-mail: mehmet.a.bilen@emory.edu.
}

similar mutations are found within the two types of PRCC, each type has characteristic common mutations. Type 1 PRCC is more associated with MET alterations, either genetic mutations or gain of chromosome 7 where the MET gene is found. Type 2 PRCC tends to have mutations in CDKN2A, SETD2, BAP1, PBRM1, TERT, NF2, FH, and NRF2-ARE pathway genes. Type 2 is also associated with a $\mathrm{CpG}$ island methylator phenotype (CIMP) (Table 1) [6-8].

MET mutations in PRCC were first identified in hereditary PRCC as an autosomal dominant mutation in the MET gene on chromosome 7q31 $[9,10]$. Since then, additional somatic mutations and chromosome duplications have been identified in sporadic renal carcinoma [8]. MET mutations are also found in other malignancies, such as hepatocellular carcinomas (HCC), lung cancer, breast cancer, colorectal cancer (CRC), head and neck squamous cell cancers (HNSCC), gastric carcinomas (GC), and cancers of 
Table 1

Common Mutations in PRCC

\begin{tabular}{ll}
\hline Type 1 PRCC & Type 2 PRCC \\
\hline MET mutations & CDKN2A \\
Gain of chromosome 7 & SETD2 \\
& BAP1 \\
& PBRM1 \\
& CpG island methylation \\
& NRF2-ARE pathway genes (NFE2L2, \\
& CUL3, KEAP1, and SIRT1) \\
\hline
\end{tabular}

unknown primary origin [7]. Increased expression of MET can occur via overexpression, gene amplification, activating point mutations, gene fusions, increased chromosome 7 copy number, paracrine signaling, autocrine loop formation, receptor mutations, and splice variants [10-13]. Although MET alterations are more common in type 1 PRCC, one study found a larger percentage of type 2 PRCC with MET mutations than previously identified, with $46 \%$ of type 2 and $81 \%$ of type 1 PRCC cases positive for MET mutation [14].

\section{THE MET PATHWAY}

MET is a tyrosine kinase receptor of hepatocyte growth factor/scatter factor (HGF/SF). This pathway is involved in a variety of normal functions, including: liver regeneration, wound healing, organ morphogen- esis, and embryo development [11]. In normal tissues, HGF and MET are upregulated after renal injury as a mechanism of tissue repair and regeneration. In oncogenesis, MET is involved in invasion, anti-apoptosis, angiogenesis, and metastasis (Fig. 1).

There is also influence from other growth factors, such as epidermal growth factor receptor (EGFR) activation of c-MET after stimulation of cells with EGF or transforming growth factor (TGF- $\alpha$ ) (Fig. 1) [13]. This interaction is further evidenced in nonsmall cell lung carcinomas (NSCLC) with acquired resistance to EGFR inhibitors due to amplifications in MET.

\section{PRCC OUTCOMES WITH CONVENTIONAL THERAPY}

PRCC tends to have a less robust response to conventional therapy used in RCC compared with clear cell carcinoma (ccRCC) given that ccRCC is associated with distinct mutations not typically found in PRCC, such as VHL and PBRM1 [15-20]. Multiple large studies have found significantly lower response rates with shorter median progression-free survival (PFS) and overall survival (OS) in patients with non-ccRCC variants, such as PRCC, when compared to ccRCC. One large study of 5474 patients with metastatic RCC showed better OS, PFS, and

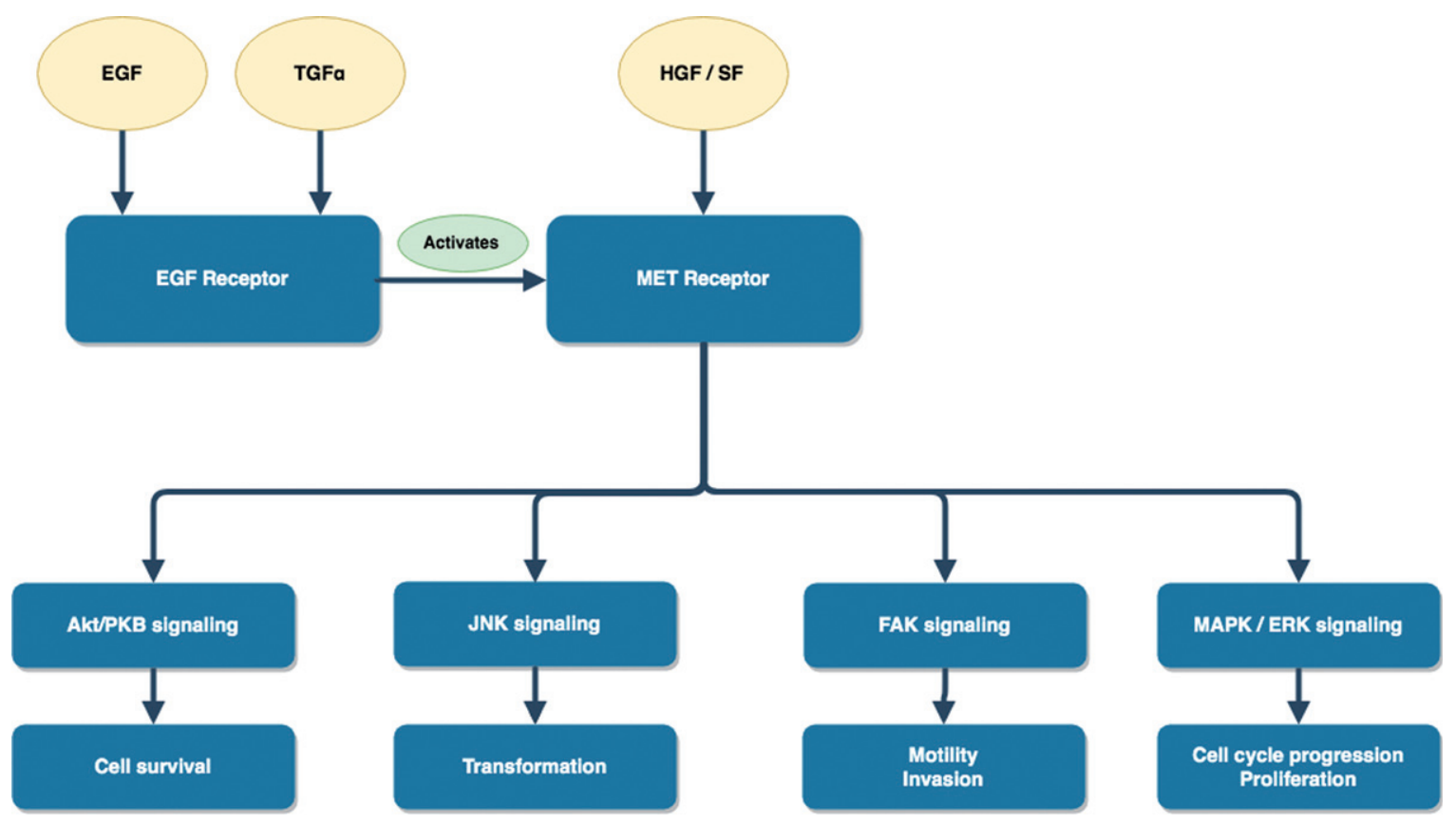

Fig. 1. MET molecular pathway. 
objective response rate (ORR) for ccRCC compared to non-ccRCC with an OS 8 months longer for ccRCC [17]. Another large systematic review and meta-analysis evaluating 49 studies composed of 7771 patients found that non-ccRCC had significantly lower response rates compared with ccRCC, with a $10.5 \%$ overall response rate in non-ccRCC. Among patients with non-ccRCC, median PFS and OS were 7.4 and 13.4 months, respectively. For patients with ccRCC, these clinical outcomes were significantly higher with a PFS and OS of 10.5 months and 15.7 months, respectively [16]. Therapeutic interventions (including bevacizumab, sorafenib, sunitinib, temsirolimus, and sunitinib) were less effective for patients with non-ccRCC with a response rate of $9.2 \%$ compared to $14.8 \%$ in ccRCC [16].

When evaluating specific agents used in RCC, the efficacy is diminished for non-ccRCC compared to ccRCC. One example is everolimus. A shorter PFS was confirmed for non-ccRCC patients compared to ccRCC patients in the ASPEN, RECORD-3, and ESPN trials [18-21]. Other examples include VEGF inhibitors, such as sunitinib, which has a shorter PFS specifically in metastatic PRCC, ranging from 1.6-6.6 months, compared to 9-12 months in ccRCC [20, 22-26]. Data from meta-analyses support the use of sunitinib over everolimus and temsirolimus for metastatic non-ccRCCs in first-line treatment, but the difference in PFS is not statistically significant [27]. Based on this data, guidelines from the National Comprehensive Cancer Network (NCCN) and the European Society for Medical Oncology (ESMO) both recommend sunitinib as first line therapy in metastatic non-ccRCC [28, 29].

Immunotherapy also has a role in treating RCC. Nivolumab, a PD-L1 inhibitor, is approved for metastatic RCC, but this was based on studies excluding patients with non-ccRCC [30, 31]. For ccRCC, nivolumab improves OS with patients surviving 25 months with nivolumab versus 19.6 months with everolimus [30]. For non-ccRCC, a few case reports describe responses of patients with PRCC to nivolumab [32-34]. In 2018, a study from Koshkin et al. evaluated nivolumab in non-ccRCC with 16 of 41 patients having PRCC. The study found clinical response to nivolumab seen as an ORR of $20 \%$ and stable disease (SD) in $29 \%$ of all patients in the study. Results specific to the 16 patients with PRCC, included PR of $14 \%$ and SD in $21 \%$ [35].

Given the limited response of PRCC to conventional therapies used in all RCC, MET-targeted therapy alone or combination with other agents could provide better outcomes for these patients. Several agents targeted to MET have been tested in RCC with varying outcomes, including tyrosine kinase inhibitors (TKI) and monoclonal antibodies (Table 2).

\section{TKIs TARGETING MET}

\section{Crizotinib}

Crizotinib is a TKI that targets MET in addition to ALK and ROS1 [34]. Currently, crizotinib is approved in NSCLC; however, there is evidence to support its use in PRCC. A phase II study, the CREATE trial, evaluated crizotinib in 23 patients with PRCC [36]. Four patients had confirmed MET alterations with two achieving partial response (PR) and a 1-year OS of $75.0 \%$ [36]. Additional evidence to support the use of crizotinib in patients with MET mutations was a small study of NSCLC patients showing PR more often with high level MET genomic amplification [35]. Currently, there are phase II trials evaluating the use of crizotinib in RCC, NSCLC, and anaplastic large cell lymphoma (Table 3) [38, 39]. Recently, the crizotinib arm in the SWOG 1500 trial (NCT02761057) was closed for accrual.

\section{Savolitinib}

Savolitinib is a small molecule inhibitor of MET that was initially found to induce tumor regression in PRCC xenograft models in vivo [40]. A later study of savolitinib in PRCC patients found a PR in $18 \%$ of participants with MET-driven disease and none with MET-independent disease $(\mathrm{P}=0.002)$ [41]. Savolitinib was part of a phase II trial, SWOG 1500, evaluating MET inhibitors in PRCC, but this arm was recently closed for accrual (NCT02761057) [39]. Phase III trials are underway investigating savolitinib compared to sunitinib for MET alteration-driven PRCC (NCT03091192) (Table 3) [41, 42].

\section{Cabozantinib}

Cabozantinib is another TKI that targets multiple receptors, including c-MET, VEGF, RET, KIT, AXL, TIE2, and FLT3 [43]. Data from phase I study from Choueiri et al. demonstrated safety and tolerability in RCC [44]. The phase 3 trial, METEOR, found significant improvement in OS for advanced ccRCC patients who received cabozantinib compared to everolimus (OS 21.4 months vs 17.1 months) [44]. 
Table 2

Current Data on MET inhibitors in PRCC

\begin{tabular}{|c|c|c|c|c|}
\hline Drug & Molecular Targets & Current Data in PRCC & FDA Approval & References \\
\hline Crizotinib & $\begin{array}{l}\text { MET } \\
\text { ALK } \\
\text { ROS1 }\end{array}$ & $\begin{array}{l}\text { Schöffski } P \text {, et al. } \\
\text { - phase II trial, CREATE } \\
-23 \text { patientswith PRCC }- \text { ORR }=50 \%(2 / 4 \\
\text { patients with MET alterations with a PR }) \\
\text { - } 1 \text {-year OS }=75 \%\end{array}$ & $\begin{array}{l}\text { NSCLC with } \\
\text { mutations in: ROS-1, } \\
\text { ALK, or MET }\end{array}$ & 36,37 \\
\hline Savolitinib & MET & $\begin{array}{l}\text { Choueiri TK, et al. } \\
\text { - phase II trial } \\
\text { - } 109 \text { patients with PRCC, } 44 \text { with } \\
\text { MET-driven disease } \\
-\mathrm{PR}=18 \% \text { in MET-driven disease }\end{array}$ & None & 40,41 \\
\hline Cabozantinib & $\begin{array}{l}\text { MET, VEGF, RET, KIT, } \\
\text { AXL, TIE2, FLT3 }\end{array}$ & $\begin{array}{l}\text { Campbell MT, et al. } \\
\text { - Retrospective } \\
\text { - } 30 \text { patients with non-ccRCC, } 57 \% \text { with } \\
\text { PRCC } \\
\text { - ORR of } 14.3 \% \\
\text { Chanza NM, et al. } \\
\text { - Retrospective } \\
\text { - } 80 \text { patients with non-ccRCC, } 59 \% \text { with } \\
\text { PRCC } \\
\text { - ORR of } 27.3 \%\end{array}$ & $\mathrm{RCC}$ & $43-48$ \\
\hline Foretinib & $\begin{array}{l}\text { MET, VEGFR2, RON, } \\
\text { AXL, TIE-2 }\end{array}$ & $\begin{array}{l}\text { Choueiri TK, et al. } \\
\text { - phase II trial } \\
\text { - } 74 \text { patients with PRCC } \\
\text { - PFS } 9.3 \text { mon } \\
\text { - PR: } 50 \% \text { for germline MET mutations ( } 5 \\
\text { of } 10 \text { patients), } 20 \% \text { for somatic MET } \\
\text { mutation ( } 1 \text { of } 5 \text { patients), } 9 \% \text { without a } \\
\text { MET mutation ( } 5 \text { of } 57 \text { patients), } 5 \% \text { with a } \\
\text { gain of chromosome } 7 \text { ( } 1 \text { of } 18 \text { patients), and } \\
\text { none in patients with MET amplification ( } 2 \\
\text { patients) }\end{array}$ & None & $50-54$ \\
\hline Tivantinib & MET & $\begin{array}{l}\text { Twardowski PW, et al. } \\
\text { - phase II trial (SWOG 1107) } \\
\text { - } 50 \text { patients, } 48 \% \text { with confirmed PRCC } \\
\text { - no clinical activity with either tivantinib } \\
\text { alone or in combination with erlotinib }\end{array}$ & None & 54,55 \\
\hline Rilotumumab & $\begin{array}{l}\text { Fully human IgG2 mAb } \\
\text { directed against HGF }\end{array}$ & $\begin{array}{l}\text { Schöffski } P \text {, et al. } \\
\text { - phase II trial } \\
\text { - } 61 \text { patients with RCC } \\
\text { - no objective responses }\end{array}$ & None & 58,59 \\
\hline ARGX-111 & $\begin{array}{l}\text { Antibody that blocks } \\
\text { HGF/MET }\end{array}$ & $\begin{array}{l}\text { Aftimos } P G \text {, et al. } \\
\text { - phase } 1 \mathrm{~b} \text { trial } \\
\text { - } 16 \text { patients with multiple solid tumors, } 3 \\
\text { with RCC } \\
\text { - demonstrated safety }\end{array}$ & None & $60-62$ \\
\hline LY3164530 & Antibody to EGFR/MET & $\begin{array}{l}\text { Patanik A, et al. } \\
\text { - phase I trial } \\
\text { - } 36 \text { patients with various solid tumors, } \\
\text { including PRCC } \\
\text { - progressive disease in PRCC } \\
\text { - significant toxicities and no predictive } \\
\text { biomarker }\end{array}$ & None & 64,65 \\
\hline
\end{tabular}


Table 3

Ongoing Trials for PRCC

\begin{tabular}{|c|c|c|c|}
\hline Drug & Targets & NCT ID & Trial Details \\
\hline \multirow[t]{3}{*}{ Crizotinib } & MET & \multirow[t]{3}{*}{ NCT02761057 [39] } & \multirow{3}{*}{$\begin{array}{l}\text { - Phase II trial (SWOG 1500): Evaluating } \\
\text { cabozantinib, crizotinib, savolitinib,or } \\
\text { sunitinib in PRCC }\end{array}$} \\
\hline & ALK & & \\
\hline & ROS1 & & \\
\hline \multirow[t]{2}{*}{ Savolitinib } & MET & NCT03091192 [42] & $\begin{array}{l}\text { - Phase III trial: Evaluating savolitinib vs } \\
\text { sunitinib in MET driven PRCC }\end{array}$ \\
\hline & & NCT02761057 [39] & $\begin{array}{l}\text { - Phase II trial (SWOG 1500): Evaluating } \\
\text { cabozantinib, crizotinib, savolitinib,or } \\
\text { sunitinib in PRCC. }\end{array}$ \\
\hline Cabozantinib & $\begin{array}{l}\text { MET, VEGF, RET, KIT, } \\
\text { AXL, TIE2, FLT3 }\end{array}$ & NCT02761057 [39] & $\begin{array}{l}\text { - Phase II trial (SWOG 1500): Evaluating } \\
\text { cabozantinib, crizotinib, savolitinib,or } \\
\text { sunitinib in PRCC }\end{array}$ \\
\hline Capmatinib & MET & NCT02019693 [82] & $\begin{array}{l}\text { - Phase II trial: Evaluating capmatinib in } \\
\text { PRCC }\end{array}$ \\
\hline Nivolumab+/- ipilimumab & $\begin{array}{l}\text { anti-PD-1 + anti-CTLA-4 } \\
\text { mAb }\end{array}$ & NCT03177239 [72] & $\begin{array}{l}\text { - Phase II trial: sequential treatment of } \\
\text { nivolumab followed by } \\
\text { nivolumab+ipilimumab if single agent } \\
\text { treatment is not effective in PRCC }\end{array}$ \\
\hline $\begin{array}{l}\text { Savolitinib or } \\
\text { Tremelimumab with } \\
\text { Durvalumab }\end{array}$ & $\begin{array}{l}\text { MET TKI or anti-CTLA-4 } \\
\text { with anti-PD-L1 }\end{array}$ & NCT02819596 [71] & $\begin{array}{l}\text { - Phase II trial: evaluating savolitinib, } \\
\text { tremelimumab, durvalumab alone or in } \\
\text { combination in PRCC and ccRCC }\end{array}$ \\
\hline
\end{tabular}

A Phase II study, CABOSUN, looking at cabozantinib compared to sunitinib in metastatic intermediate/poor risk ccRCC patients found prolonged PFS in the cabozantinib arm (8.6 months vs 5.3 months) [45]. As a result, cabozantinib has been approved for use in RCC as first or second line in this population (46). Retrospective studies have reported clinical response with cabozantinib specifically in PRCC patients [47, 48]. One study composed of 57\% PRCC (total of 30 non-ccRCC patients) found a median PFS of 8.6 months and OS of 25.4 months. SD was achieved in $64.2 \%$ patients with an ORR of $14.3 \%$ [47]. Another study showed cabozantinib is safe and active in PRCC with $27.3 \%$ ORR, median OS of 11 months and a time to treatment failure of 6.9 months [48]. Currently, a phase II trial is evaluating cabozantinib and other MET targeted therapies specifically in PRCC (NCT02761057) (Table 3) [39].

\section{Foretinib}

Foretinib is a TKI against MET, VEGFR2, RON, AXL, and TIE-2 [49]. The dual targeting of MET and VEGF resulted in a median PFS of 9.3 months in non-ccRCC, which is comparable to responses seen in ccRCC patients treated with VEGF inhibitors. Germline MET mutations tended to correlate best with patient response to the drug with $50 \%$ (five of ten patients) achieving a PR. PR was seen in $20 \%$ of patients with a somatic MET mutation (one of five patients), $9 \%$ without a MET mutation (five of 57 patients), $5 \%$ with a gain of chromosome 7 (one of 18 patients), and none in patients with MET amplification (zero of two patients) [49]. Most recent studies of foretinib have involved breast cancer and NSCLC patients [50-52].

\section{Tivantinib}

Tivantinib is a selective non-competitive c-MET inhibitor that was initially found in phase I studies to induce disease stabilization in three of five patients with non-ccRCC [53, 54]. Later phase 2 evaluation in the SWOG S1107 cohort found no clinical activity in patients with advanced PRCC with either tivantinib alone or in combination with erlotinib, an EGFR inhibitor. However, these results reflect a patient population predominately composed of type 2 PRCC (42\%). Notably, only $6 \%$ of patients had type 1 PRCC and only 1 of 16 tissue samples sequenced had a MET alteration; therefore, it is difficult to draw definitive conclusions about the use of tivantinib in PRCC patients with identified MET mutations [55]. Ultimately, the study was terminated due to increased incidence of interstitial lung disease and projected futility during analysis. 


\section{Amuvatinib}

Amuvatinib is a TKI that inhibits MET in addition to c-kit, Flt3, AXL, and PDGFR alpha. Initial phase 2 studies were conducted in small cell lung cancer (SCLC) and did not meet clinical primary endpoint, so further clinical development of this agent was discontinued [56, 57].

\section{MONOCLONAL ANTIBODIES TARGETING MET}

\section{Rilotumumab}

Rilotumumab (AMG 102), a fully human IgG2 $\mathrm{mAb}$ directed against HGF, was initially evaluated as a targeted therapy in renal cancers and glioblastomas to inhibit MET-mediated signal transduction leading to apoptosis in c-MET expressing cells [58]. However, studies of the drug were stopped early due to poor outcomes. A phase II study evaluating activity of rilotumumab in mRCC including PRCC showed no ORR [59].

\section{$A R G X-111$}

ARGX-111, is an antagonistic anti-MET antibody that blocks HGF/MET and kills MET-overexpressing cells via antibody-dependent cellular cytotoxicity [58]. The drug competes with HGF for MET binding, inhibits ligand-dependent MET activity, downregulates cell surface expression of MET, decreases HGF-independent MET activity, and engages natural killer cells to kill MET-expressing cancer cells [60]. Phase $\mathrm{Ib}$ trials have demonstrated safety in patients with multiple solid tumors, including RCC, NSCLC, GC, pancreatic cancer, and cervical cancer [60-62].

\section{Onartuzumab}

Onartuzumab, a MET targeting antibody, elicited responses in patients with MET-amplified NSCLC and gastric cancer in early studies. A later phase III study of onartuzumab plus erlotinib in patients with MET-positive advanced NSCLC did not find an improvement in clinical outcomes. Median OS was 6.8 months for the onartuzumab plus erlotinib arm and 9.1 months for the erlotinib plus placebo arm; therefore, further development of onartuzumab has been halted [63].

\section{LY3164530}

LY3164530 is an anti-EGFR/MET bispecific antibody created by fusing a cetuximab variable fragment to an emibetuzumab heavy chain [64]. Phase I trials indicate future development is limited since patients experienced significant toxicities, especially renal toxicity from insoluble metabolites [65]. Additionally, the patients in this study with PRCC experienced progressive disease $[64,65]$.

\section{JNJ-61186372}

JNJ-61186372, is an EGFR/MET antibody with activity against NSCLC based on in vitro and in vivo studies [66]. Currently, phase I trials are underway and expected to be completed in 2020 [67].

\section{IMMUNE CHECKPOINT INHIBITORS AND COMBINATION THERAPIES}

There are recent studies indicating the role of immune checkpoint inhibitors specifically in non-cc RCC. A phase II study of pembrolizumab in nonccRCC with $72 \%$ of participants having PRCC, found an overall ORR of $24.8 \%$ and an ORR for PRCC of $25.4 \%$ [68]. A recent phase II study evaluating atezolizumab and bevacizumab in participants with non-ccRCC or sarcomatoid variant RCC (sscRCC) with $38.9 \%$ of participants having PRCC, found an overall ORR of $31 \%$ and an ORR for non-ccRCC of $26 \%$ [69]. SD was seen in $44 \%$ in overall population and 50\% in non-ccRCC. A study of combination therapy with durvalumab and savolitinib in metastatic PRCC was recently presented and showed an ORR of $27 \%$, SD in $39 \%$, and a PFS of 3.3 months. For MET positive patients, ORR was 20\% [70]. There are also other ongoing combination trials for PRCC. One study, MEDI4736 Combinations in Metastatic RCC (CALYPSO), investigates the use of durvalumab, savolitinib, tremelimumab alone or in combination in PRCC (NCT02819596) [71]. Another phase II study, ANZUP1602 (UNISON) looks at sequential treatment of single agent nivolumab followed by nivolumab with ipilimumab if single agent treatment is not effective in PRCC (NCT03177239) (Table 3) [72]. 


\section{OTHER AGENTS}

In addition to the TKIs and mAbs described, several additional MET inhibitors are at an early stage of investigation in pre-clinical studies or are undergoing testing in other malignancies that may have potential role in treatment of PRCC in the near future. Glesatinib, golvatinib, and AMG208 are MET TKIs shown to have activity and tolerability in phase I trials in malignancies other than PRCC [73-80]. Capmatinib is another MET TKI with in vitro activity against cells harboring METex14 alterations [81]. Although prior studies have focused on NSCLC, there is a phase II trial of capmatinib in PRCC that is ongoing [82].

There are also several mAbs targeting c-MET in early developmental stages that have largely been tested in other malignances as well. These agents include emibetuzumab and DN30 [83-91]. SAIT301 is a humanized $\mathrm{mAb}$ that promotes MET degradation that has shown activity and tolerability in MET positive patients; however, the study focused mostly on colorectal cancer [92-94]. Another drug under investigation, ABT-700, is a humanized bivalent monoclonal antibody that inhibits MET dimerization and activation with activity in cancer cell lines [91, 95]. In 2017, a phase I study was completed of ABT-700 alone and in combination with docetaxel, 5-fluorouracil, folinic acid, irinotecan and cetuximab (FOLFIRI/cetuximab) or erlotinib in patients with advanced solid tumors, with some patients harboring MET amplification or overexpression [96]. Additionally, a phase I study of telisotuzumab vedotin (Teliso-V), an antibody-drug conjugate of ABT-700 and monomethyl auristatin E, in NSCLC patients who carried a MET alteration found a PFS of 5.7 months in three of 16 patients with c-MET-positive NSCLC [97]. Phase II studies are underway [98].

\section{CONCLUSION}

MET is an appealing drug target given its prevalence in PRCC. Developing effective MET targeted therapies is needed since outcomes are typically worse for PRCC when treated with conventional therapies. Therapeutic interventions targeted to the MET pathway in PRCC are still under active investigation, such as, MET TKIs and MET-directed antibodies. There is a need for continued research into MET-targeted therapy and more studies to include patients with PRCC. Additionally, recent studies indicate that there may be a role for immune checkpoint inhibitors alone or combination with MET inhibitors in treatment of PRCC. Going forward, PRCC patients may benefit from targeting multiple components of the MET pathway, targeting pathways that are known to interact with the MET pathway, and incorporating immune checkpoint inhibitors.

\section{ACKNOWLEDGMENTS}

We thank Anthea Hammond from the Emory University Department of Hematology and Medical Oncology for editing this manuscript. Research reported in this publication was supported in part by the Winship Cancer Institute of Emory University and NIH/NCI under award number P30CA138292. The content is solely the responsibility of the authors and does not necessarily represent the official views of the National Institutes of Health.

\section{CONFLICTS OF INTEREST}

M.A. Bilen has a consulting/advisory role with Exelixis, Nektar, Genomic Health, EMD Serono and Sanofi and receives institutional research funding from Bayer, Bristol-Myers Squibb, Genentech/Roche, Incyte, Nektar, AstraZeneca, Tricon Pharmaceuticals, Peloton, and Pfizer.

\section{REFERENCES}

[1] Siegel RL, Miller KD, Jemal A. Cancer statistics, 2018. CA Cancer J Clin. 2018;68:7-30. https://doi.org/10.3322/caac. 21442.

[2] Capitanio U, Montorsi, F. Renal cancer. Lancet. 2016; 387(1001):894-906. https://doi.org/10.1016/S0140-6736 (15)00046-X.

[3] Ferlay J, Soerjomataram I, Ervik M, et al. Cancer incidence and mortality worldwide: Sources, methods and major patterns in GLOBOCAN 2012. Int J Cancer. 2015; 136(5):E359-86. https://doi.org/10.1002/ijc.29210.

[4] Capitanio U, Bensalah K, Bex A, et al. Epidemiology of renal cell carcinoma. Eur Urol. 2018;75(1):74-84. https:// doi.org/10.1016/j.eururo.2018.08.036.

[5] Surveillance, Epidemiology, and End Results Program. SEER stat fact sheets: Kidney and renal pelvis cancer. Bethesda, MD: National Cancer Institute. [cited 2018 December 20]. Available from: http://seer.cancer.gov/ statfacts/html/kidrp.html.

[6] Pal SK, Ali SM, Yakirevich E, et al. Characterization of clinical cases of advanced papillary renal cell carcinoma via comprehensive genomic profiling. European Urology. 2018;73(1):71-8. https://doi.org/10.1016/j.eururo. 2017.05.033.

[7] The Cancer Genome Atlas Network. Comprehensive molecular characterization of papillary renal-cell carcinoma. $\mathrm{N}$ 
Engl J Med. 2015;374(2):135-45. https://doi.org/10.1056/ NEJMoa1505917.

[8] Tovar EA and Graveer CR. MET in human cancer: Germline and somatic mutations. Ann Transl Med. 2017;5(10):205. https://doi.org/10.21037/atm.2017.03.64.

[9] Hass NB, Nathanson KL. Hereditary renal cancer syndromes. Adv Chronic Kidney Dis. 2014;21(1):81-90. https://doi.org/10.1053/j.ackd.2013.10.001.

[10] Linehan WM, Spellman PT, Ricketts CJ, et al. Comprehensive molecular characterization of papillary renalcell carcinoma. N Engl J Med. 2016;374(2):135-45. https://doi.org/10.1056/NEJMoa1505917.

[11] Zenali M, deKay J, Liu Z, et al. Retrospective review of MET gene mutations. Oncoscience. 2015;2(5):533-41. https://doi.org/10.18632/oncoscience.161.

[12] Giubellino A, Linehan WM, Bottaro DP. Targeting the Met signaling pathway in renal cancer. Expert Rev Anticancer Ther. 2009;9(6):785-93. https://doi.org/10.1586/era.09.43.

[13] Organ SL, Tsao M-S. An overview of the c-MET signaling pathway. Ther Adv Med Oncol. 2011;3:S7-19. https://doi.org/10.1177/1758834011422556.

[14] Albiges L, Guegan J, Le Formal A, et al. MET is a potential target across all papillary renal cell carcinomas: Results from a large molecular study of pRCC with CGH array and matching gene expression array. Clin Cancer Res. 2014;20(13):3411-21. https://doi.org/10.1158/10780432.CCR-13-2173.

[15] The Cancer Genome Atlas Research Network. Comprehensive molecular characterization of clear cell renal cell carcinoma. Nature. 2014;499(7456):43-49. https://doi.org/10.1038/nature12222.

[16] Vera-Badillo FE, Templeton AJ, Duran I, et al. Systemic therapy for non-clear cell renal cell carcinomas: A systematic review and meta-analysis. Eur Urol. 2015;67(4):740-9. https://doi.org/10.1016/j.eururo.2014.05.010.

[17] Connor Wells J, Donskov F, Fraccon AP, et al. Characterizing the outcomes of metastatic papillary renal cell carcinoma. 2017;6(5):902-9. https://doi.org/10.1002/cam4. 1048.

[18] Armstrong AJ, Halabi S, Eisen T, et al. Everolimus versus sunitinib for patients with metastatic non-clear cell renal cell carcinoma (ASPEN): A multicentre, open-label, randomised phase 2 trial. Lancet Oncol. 2016;17(3):378-88. https://doi.org/10.1016/S1470-2045(15)00515-X.

[19] Motzer RJ, Barrios CH, Kim TM, et al. Phase II randomized trial comparing sequential first-line everolimus and secondline sunitinib versus first-line sunitinib and second-line everolimus in patients with metastatic renal cell carcinoma. J Clin Oncol. 2014;32(25):2765-72. https://doi.org/ 10.1200/JCO.2013.54.6911.

[20] Tannir NM, Jonasch E, Albiges L, et al. Everolimus versus sunitinib prospective evaluation in metastatic nonclear cell renal cell carcinoma (ESPN): A randomized multicenter phase 2 trial. Eur Urol. 2016;69(5):866-74. https://doi.org/10.1016/j.eururo.2015.10.049.

[21] Buti S, Leonetti A, Dallatomasina A, et al. Everolimus in the management of metastatic renal cell carcinoma: An evidence-based review of its place in therapy. Core Evid. 2016;11:23-36. https://doi.org/10.2147/CE.S98687.

[22] Motzer RJ, Escudier B, Powles T, et al. Long-term followup of overall survival for cabozantinib versus everolimus in advanced renal cell carcinoma. BJC. 2018;118(9):1176-8. https://doi.org/10.1038/s41416-018-0061-6.

[23] Motzer RJ, Hutson TE, Cella D, et al. Pazopanib versus sunitinib in metastatic renal-cell carcinoma. $\mathrm{N}$
Engl J Med. 2013;369(8):722-31. https://doi.org/10.1056/ NEJMoa1303989.

[24] Motzer RJ, Hutson TE, Tomczak P, et al. Sunitinib versus interferon alfa in metastatic renal-cell carcinoma. N Engl J Med. 2007;356(2):115-24. https://doi.org/10.1056/ NEJMoa065044.

[25] Tannir NM, Plimack E, Ng C, et al. A phase 2 trial of sunitinib in patients with advanced non-clear cell renal cell carcinoma. Eur Urol. 2012;62(6):1013-9. https://doi.org/ 10.1016/j.eururo.2012.06.043.

[26] Ravaud A, Oudard S, Fromont MD, et al. First line sunitinib in type I and II papillary renal cell carcinoma (PRCC): SUPAP - a phase II study of the French GenitoUrinary Group (GETUG. Ann Oncol. 2015;26(6):1123-8. https://doi.org/10.1093/annonc/mdv149.

[27] Fernandez-Pello S, Hofmann F, Tahbaz R, et al. A systematic review and meta-analysis comparing the effectiveness and adverse effects of different systemic treatments for nonclear cell renal cell carcinoma. Eur Urol 2017;71:426-36. https://doi.org/10.1016/j.eururo.2016.11.020.

[28] NCCN Clinical Practice Guidelines in Oncology (NCCN Guidelines): Kidney Cancer. [updated 2019 April 15; cited 2019 April 29]. Available from: https://www.nccn.org/ professionals/physician_gls/PDF/kidney.pdf.

[29] Escudier B, Porta C, Schmidinger M, et al. Renal cell carcinoma: ESMO Clinical Practice Guidelines for diagnosis, treatment, and follow-up. Annals of Oncology. 2019;mdz056. https://doi.org/10.1093/annonc/mdz056.

[30] Motzer RJ, Escudier B, McDermott DF, et al. Nivolumab versus everolimus in advanced renal cell carcinoma. $\mathrm{N}$ Engl J Med. 2015;373(19):1803-13. https://doi.org/10.1056/ NEJMoa1510665.

[31] George S, Motzer RJ, Hammers HJ, et al. Safety and efficacy of nivolumab in patients with metastatic renal cell carcinoma treated beyond progression: A subgroup analysis of a randomized clinical trial. JAMA Oncol. 2016;2(9):1179-86. https://doi.org/10.1001/jamaoncol.2016.0775.

[32] Geynisman D. Anti-programmed cell death protein 1 (PD-1) antibody nivolumab leads to dramatic and rapid response in papillary renal cell carcinoma with sarcomatoid and rhabdoid features. Eur Urol. 2015;85(5):912-4. https://doi.org/10.1016/j.eururo.2015.07.008.

[33] Ruiz-Banobre J, Anido U, Abdulkader I, et al. Long-term response to nivolumab and acute renal failure in a patient with metastatic papillary renal cell carcinoma and a PD-L1 tumor expression increased with sunitinib therapy: A case report. Front Oncol. 2016;6:250. https://doi.org/10.3389/ fonc. 2016.00250 .

[34] Adrianzen Herrera DA, Fleisig SB, Gartrell BA. Impressive and durable response to nivolumab in a patient with metastatic type 2 papillary renal cell carcinoma: On-label but without evidence. Invest New Drugs. 2017;35(5):665-8. https://doi.org/10.1007/s10637-017-0469-5.

[35] Koshkin VS, Barata PC, Zhang T, et al. Clinical activity of nivolumab in patients with non-clear cell renal cell carcinoma. J Immunother Cancer. 2018;6(1):9. https://doi. org/10.1186/s40425-018-0319-9.

[36] Schöffski P, Wozniak A, Escudier B, et al. Crizotinib achieves long-lasting disease control in advanced papillary renal-cell carcinoma type 1 patients with MET mutations or amplification. EORTC 90101 CREATE trial. Eur J Cancer. 2017;87:147-63. https://doi.org/10.1016/j.ejca. 2017.10.014.

[37] Camidge DR, Ou SH, Shapiro G, et al. Efficacy and safety of crizotinib in patients with advanced c-MET-amplified 
non-small cell lung cancer (NSCLC). J Clin Oncol. 2014;32:8001. https://doi.org/10.1200/jco.2014.32.15_sup pl.8001.

[38] Clinical Trials Using Crizotinib. National Cancer Institute. [cited 2018 December 27]. Available from: https://www. cancer.gov/about-cancer/treatment/clinical-trials/interven tion/crizotinib.

[39] Cabozantinib S-Malate, Crizotinib, Savolitinib, or Sunitinib Malate in Treating Patients With Locally Advanced or Metastatic Kidney Cancer. [updated 2019 February 20; cited 2019 February 20]. Available from: https:// clinicaltrials.gov/ct2/show/NCT02761057.

[40] Schuller AG, Barry ER, Jones RD, et al. The MET inhibitor AZD6094 (Savolitinib, HMPL-504) induces regression in papillary renal cell carcinoma patient-derived xenograft models. Clin Cancer Res. 2015;21(12):2811-9. https://doi.org/10.1158/1078-0432.CCR-14-2685.

[41] Choueiri TK, Plimack E, Arkenau H-T, et al. Biomarkerbased phase II trial of savolitinib in patients with advanced papillary renal cell cancer. J Clin Oncol. 2017;35:29933001. https://doi.org/10.1200/JCO.2017.72.2967.

[42] Savolitinib vs. Sunitinib in MET-driven PRCC. [updated 2018 December 14; cited 2019 January 15]. Available from: https://clinicaltrials.gov/ct2/show/NCT03091192.

[43] Bersanelli M, But S. Cabozantinib in metastatic renal cell carcinoma: Latest findings and clinical potential. Ther Adv Med Oncol. 2017;9(10):627-36. https://doi.org/10.1177/ 1758834017724314.

[44] Choueiri TK, Pal SK, McDermott DF, et al. A phase I study of cabozantinib (XL184) in patients with renal cell cancer.Ann Oncol. 2014;25(8):1603-8. https://doi.org/10.1093/ annonc/mdu184.

[45] Choueiri TK, Hessel C, Halabi S, et al. Cabozantinib versus sunitinib as initial therapy for metastatic renal cell carcinoma of intermediate or poor risk (Alliance A031203 CABOSUN randomised trial): Progression-free survival by independent review and overall survival update. Eur J Cancer. 2018;94:115-125. https://doi.org/10.1016/ j.ejca.2018.02.012.

[46] FDA grants regular approval to Cabometyx for first-line treatment of advanced renal cell carcinoma. US FDA. [updated 2017 December 19; cited 2018 December 27]. Available from: https://www.fda.gov/Drugs/Information OnDrugs/ApprovedDrugs/ucm589842.htm

[47] Campbell MT, Bilen MA, Shah AY, et al. Cabozantinib for the treatment of patients with metastatic non-clear cell renal cell carcinoma: A retrospective analysis. Eur J Cancer. 2018;104:188-94. https://doi.org/10.1016/j.ejca. 2018.08.014.

[48] Chanza NM, Bosse D, Bilen MA, et al. Cabozantinib (Cabo) in advanced non-clear cell renal cell carcinoma (nccRCC): A retrospective multicenter analysis. J Clin Oncol. 2018;36:abstr 4579.

[49] Choueiri TK, Vaishampayan U, Rosenberg JE, et al. Phase II and biomarker study of the dual MET/VEGFR2 inhibitor foretinib in patients with papillary renal cell carcinoma. J Clin Oncol. 2013;31:181-6. https://doi.org/10.1200/JCO. 2012.43.3383.

[50] Rayson D, Lupichuk S, Potvin K, et al. Canadian Cancer Trials Group IND197: A phase II study of foretinib in patients with estrogen receptor, progesterone receptor, and human epidermal growth factor receptor 2-negative recurrent or metastatic breast cancer. Breast Cancer Res Treat. 2016;157(1):109-16. https://doi.org/10.1007/s10549-0163812-1.
[51] Chia SK, Ellard SL, Mates Mihaela, et al. A phase-I study of lapatinib in combination with foretinib, a c-MET, AXL and vascular endothelial growth factor receptor inhibitor, in human epidermal growth factor receptor 2 (HER-2)-positive metastatic breast cancer. Breast Cancer Res. 2017;19:54. https://doi.org/10.1186/s13058-017-0836-3.

[52] Leighl NB, Tsao M-S, Liu Geoffery, et al. A phase I study of foretinib plus erlotinib in patients with previously treated advanced non-small cell lung cancer: Canadian cancer trials group IND.196. Oncotarget. 2017;8(41):69651-62. https://doi.org/10.18632/oncotarget.18753.

[53] Zhang H, Bao z, Liao H, et al. The efficacy and safety of tivantinib in the treatment of solid tumors: A systematic review and meta-analysis. Oncotarget. 2017;8(68):11315362. https://doi.org/10.18632/oncotarget.22615.

[54] Rosen LS, Senzer N, Mekhail T, et al. A phase I dose-escalation study of tivantinib (ARQ 197) in adult patients with metastatic solid tumors. Clin Cancer Res. 2011;17(24):7754-64. https://doi.org/10.1158/10780432.CCR-11-1002.

[55] Twardowski PW, Tangen CM, Wu X, et al. Parallel (randomized) phase II evaluation of tivantinib (ARQ197) and tivantinib in combination with erlotinib in papillary renal cell carcinoma: SWOG S1107. Kidney Cancer. 2017;1(2):123-32. https://doi.org/10.3233/KCA170018.

[56] Myers SH, Brunton VG, Unciti-Broceta A. AXL inhibitors in cancer: A medicinal chemistry perspective. Med Chem. 2016;59(8):3593-360. https://doi.org/10.1021/ acs.jmedchem.5b01273.

[57] Byers LA, Horn L, Ghandi J, et al. A phase 2, open-label, multi-center study of amuvatinib in combination with platinum etoposdie chemotherapy in platinum refractory small cell lung cancer patients. Oncotarget. 2017;8(46):81441-54. https://doi.org/10.18632/oncotarget.19888.

[58] Comoglio PM, Giordano S, Trusolino L. Drug development of MET inhibitors: Targeting oncogene addiction and expedience. Nat Rev Drug Discov. 2008;7(6):504-16. https://doi.org/10.1038/nrd2530.

[59] Schöffski P, Garcia JA, Stadler WM, et al. A phase II study of the efficacy and safety of AMG 102 in patients with metastatic renal cell carcinoma. BJU Int. 2011;108(5):67986. https://doi.org/10.1111/j.1464-410X.2010.09947.

[60] Hultberg, A, Moreelo V, HuygheL, et al. Depleting METexpressing tumor cells by ADCC provides a therapeutic advantage over inhibiting HGF/MET signaling. Cancer Res. 2015;75(16):3373-83. https://doi.org/10.1158/00085472.CAN-15-0356.

[61] Aftimos PG, Barthelemy P, Rolfo CD, et al. A phase I, first-in-human study of $\operatorname{argx}-111$, a monoclonal antibody targeting c-met in patients with solid tumors. J Clin Oncol. 2017;33:2580. https://doi.org/10.1200/jco.2015.33.15_sup pl.2580.

[62] Argenx presents full data from ARGX-111 Phase Ib study in patients with advanced cancers over-expressing the MET protein at Best of ASCO Asia 2017 (Singapore). Argenx. [updated 2017 July 07; cited 2018 Dec 27]. https://www.argenx.com/en-GB/news-internal/argenx-pre sents-full-data-from-argx-111-phase-ib-study-in-patientswith-advanced-cancers-over-expressing-the-met-proteinat-best-of-asco-asia-2017-singapore/20153/.

[63] Charakidis M,Boyer M. Targeting MET and EGFR in NSCLC-what can we learn from the recently reported phase III trial of onartuzumab in combination with erlotinib in advanced non-small cell lung cancer? Transl Lung 
Cancer Res. 2014;3:395-6. https://doi.org/10.3978/j.issn. 2218-6751.2014.09.03.

[64] Patanik A, Gordon M, Tsai F, et al. A phase I study of LY3164530, a bispecific antibody targeting MET and EGFR, in patients with advanced or metastatic cancer. Cancer Chemother Pharmacol. 2018;82(3):407-18. https://doi.org/10.1007/s00280-018-3623-7.

[65] Lolkema MP, Bohets HH, Arkenau HT, et al. The c-Met tyrosine kinase inhibitor JNJ-38877605 causes renal toxicity through species-specific insoluble metabolite formation. Clin Cancer Res. 2015;21(10):2297-304. https://doi.org/10.1158/1078-0432.CCR-14-3258.

[66] Moores SL,Chiu ML,Bushey BS, et al. A novel bispecific antibody targeting EGFR and cMet is effective against EGFR inhibitor-resistant lung tumors. Cancer Res. 2016;76(13):3942-53. https://doi.org/10.1158/00085472.CAN-15-2833.

[67] A Dose Escalation Study of JNJ-61186372 in participants with advanced non-small cell lung cancer. ClinicalTrials.gov [updated 2019 January 3, cited 2019 January 6]. Available from: https://clinicaltrials.gov/ct2/ show/NCT02609776.

[68] McDermott DF, Lee J-L, Ziobro M, et al. First-line pembrolizumab (pembro) monotherapy for advanced nonclear cell renal cell carcinoma (nccRCC): Results from KEYNOTE-427 cohort B. J Clin Oncol. 2019;37:abstr 546.

[69] McKay RR, McGregor BA, Gray K, et al. Results of a phase II study of atezolizumab and bevacizumab in non-clear cell renal cell carcinoma (nccRCC) and clear cell renal cell carcinoma with sarcomatoid differentiation (sccRCC). J Clin Oncol. 2019;37:abstr 548.

[70] Powles T, Larkin JMG, Patel P, et al. A phase II study investigating the safety and efficacy of savolitinib and durvalumab in metastatic papillary renal cancer (CALYPSO). J Clin Oncol. 2019;37:abstr 545.

[71] MEDI4736 Combinations in Metastatic Renal Cell Carcinoma (CALYPSO). [updated 2017 August 28; cited 2019 February 20]. Available from: https://clinicaltrials.gov/ ct2/show/NCT02819596.

[72] Phase II Sequential Treatment Trial of Single Agent Nivolumab, Then Combination Ipilimumab+Nivolumab in Metastatic or Unresectable Non-Clear Cell Renal Cell Carcinoma (ANZUP1602) (UNISoN). [updated 2018 June 29; cited 2019 February 20]. Available from: https:// clinicaltrials.gov/ct2/show/NCT03177239.

[73] Engstrom LD, Aranda R, Lee M, et al. Glesatinib exhibits antitumor activity in lung cancer models and patients harboringMETExon 14 mutations and overcomes mutation-mediated resistance to type I MET inhibitors in nonclinical models. Clin Cancer Res. 2017;23(21):6661-72. https://doi.org/10.1158/1078-0432.CCR-17-1192.

[74] Kollmannsberger CK, Sharma S, Shapiro G, et al. Phase I study of receptor tyrosine kinase (RTK) inhibitor, MGCD265, in patients (pts) with advanced solid tumors. J Clin Oncol. 2017;33:2589. https://doi.org/10.1200/jco. 2015.33.15_suppl.2589.

[75] Mirati Therapeutics Provides Update On Glesatinib And Sitravatinib Clinical Trials And Pipeline Programs. PR Newswire. [updated 2017 January 05; cited 2018 December 27]. Available from: http://ir.mirati.com/newsreleases/news-release-details/mirati-therapeutics-providesupdate-glesatinib-and-sitravatinib.

[76] Molife LR, Dean EJ, Blanco-Codesido M, et al. A phase I, dose-escalation study of the multitargeted recep- tor tyrosine kinase inhibitor, golvatinib, in patients with advanced solid tumors. Clin Cancer Res. 2014;20(24):628494. https://doi.org/10.1158/1078-0432.CCR-14-0409.

[77] Yao S, Nakagawa T. The current state of molecularly targeted drugs targeting HGF/Met. Japanese Journal of Clinical Oncology. 2014;44(1):9-12. https://doi.org/10.1093/ jjco/hyt 188

[78] O'Neil BH, Bendell JC, Modiano MR, et al. Phase I/II study of E7050 (golvantinib) in combination with sorafenib in patients (pts) with advanced hepatocellular carcinoma (HCC): Phase I results. J Clin Oncol. 2013;31:294. https://doi.org/10.1200/jco.2013.31.4_suppl.294.

[79] Hong DS, Rosen P, Lockhart AC, et al. A first-in-human study of AMG 208, an oral MET inhibitor, in adult patients with advanced solid tumors. Oncotarget. 2015;6(21):18693706. https://doi.org/10.18632/oncotarget.4472.

[80] AMG 208 Tumor Microenvironment in Metastatic Castration Resistant Prostate Cancer (mCRPC). ClinicalTrials.gov [updated 2015 April 20, cited 2018 Dec 27]. Available from: https://clinicaltrials.gov/ct2/show/NCT02420587.

[81] Frampton, GM, Ali SM, Rosenzweig, et al. Activation of MET via diverse exon 14 splicing alterations occurs in multiple tumor types and confers clinical sensitivity to MET inhibitors.Cancer Discov. 2015;5(8):850-9. https://doi.org/10.1158/2159-8290.CD-15-0285.

[82] A phase 2 study of the MET kinase inhibitor (INC280) in Papillary renal call cancer. ClinicalTrials.gov. [updated 2018 Dec 24, cited 2018 Dec 27] Available from: https://clinicaltrials.gov/ct2/show/NCT02019693.

[83] Liu L,Zeng W,Wortinger MA, et al. LY2875358, a neutralizing and internalizing anti-MET bivalent antibody, inhibits HGF-dependent and HGF-independent MET activation and tumor growth. Clin Cancer Res. 2014;20(33):6059-70. https://doi.org/10.1158/1078-0432.CCR-14-0543.

[84] Rosen LS,Goldman JW, Algazi AP, et al. A first-inhuman phase I study of a bivalent MET antibody, Emibetuzumab (LY2875358), as monotherapy and in combination with erlotinib in advanced cancer.Clin Cancer Res. 2017;23(8):1910-9. https://doi.org/10.1158/10780432.CCR-16-1418.

[85] Camidge DR, Moran T, Demedts I, et al. A randomized, open-label, phase 2 study of emibetuzumab plus erlotinib $(\mathrm{LY}+\mathrm{E})$ and emibetuzumab monotherapy (LY) in patients with acquired resistance to erlotinib and MET diagnostic positive (MET Dx+) metastatic NSCLC. J Clin Oncol. 2017;34:9070. https://doi.org/10.1200/JCO.2016.34.15_su ppl.9070.

[86] Scagliotti GV, Moro-Sibilot D, Kollmeier J, et al. A randomized, controlled, open label phase II study of erlotinib (E) with or without the MET antibody emibetuzumab (Emi) as first-line treatment forEGFRmt non-small cell lung cancer (NSCLC) patients who have disease control after an 8-week lead-in treatment with erlotinib. J Clin Oncol. 2017;35:9019. https://doi.org/10.1200/JCO.2017.35.15_su ppl.9019.

[87] Sakai D, Chung HC, Oh DY, et al. A non-randomized, openlabel, single-arm, phase 2 study of emibetuzumab in Asian patients with MET diagnostic positive, advanced gastric cancer. Cancer Chemother Pharmacol. 2017;80(6):1197207. https://doi.org/10.1007/s00280-017-3445-z.

[88] A Study of emibetuzumab in Non Small Cell Lung Cancer (NSCLC) Participants (Chime). ClinicalTrials.gov [updated 2018 June 25, cited 2018 Dec 27]. Available from: https://clinicaltrials.gov/ct2/show/NCT01900652. 
[89] Pacchiana G, Chiriaco C, Stella MC, et al. Monovalency unleashes the full therapeutic potential of the DN-30 anti-Met antibody. J Biol Chem. 2010;285(46):36149-57. https://doi.org/10.1074/jbc.M110.134031.

[90] Vigna E, Petronzelli F, Giordano S, et al. A chimeric antibody (MV-DN30) inhibiting. J Clin Oncol. 2017;32:4019. https://doi.org/10.1200/jco.2014.32.15_suppl.e14019.

[91] Kim K-H, Kim H. Progress of antibody-based inhibitors of the HGF-cMET axis in cancer therapy. Exp Mol Med. 2017;49(3):e307. https://doi.org/10.1038/emm.2017.17.

[92] Lee JM, Kim B, Lee SB, et al. Cbl-independent degradation of Met: Ways to avoid agonism of bivalent Met-targeting antibody. Oncogene. 2014;33(1):34-43. https://doi.org/ 10.1038/onc.2012.551.

[93] Lee B-S, Kang S, Kim K-A, et al. Met degradation by SAIT301, a Met monoclonal antibody, reduces the invasion and migration of nasopharyngeal cancer cells via inhibition of EGR-1 expression. Cell Death Dis. 2014;5:e1159. https://doi.org/10.1038/cddis.2014.119.

[94] Lee J, Kim ST, Park S, et al. Phase I trial of anti-met monoclonal antibody in MET-overexpressed refractory cancer. Clin Colorectal Cancer. 2018;17(2):140-6. https:// doi.org/10.1016/j.clcc.2018.01.005.
[95] Kang W-K, LoRusso P, Salgia R, et al. Phase I study of ABT-700, an anti-c-Met antibody, in patients (pts) with advanced gastric or esophageal cancer (GEC). J Clin Oncol. 2015;33:167. https://doi.org/10.1200/jco.2015. 33.3_suppl.167.

[96] Study of ABT-700 in subjects with advanced solid tumors. ClinicalTrials.gov. [updated 2017 November 21; cited 2018 December 27]. Available from: https://clinical trials.gov/ct2/show/NCT01472016.

[97] Strickler JH, Weekes CD, Nemunaitis J, et al. Firstin-humanphaseI, dose-escalation and expansion study of telisotuzumab vedotin, anantibody-drug conjugate targeting c-met, in patients with advanced solid tumors. J Clin Oncol. 2018;36(33):3298-306. https://doi.org/10.1200/JCO.2018. 78.7697.

[98] Study of Telisotuzumab Vedotin (ABBV-399) in Subjects with Previously Treated c-MET+Non-Small Cell Lung Cancer. ClinicalTrials.gov. [updated 2018 December 10; cited 2018 December 27]. Available from: https:// clinicaltrials.gov/ct2/show/NCT03539536. 